\title{
Podstawa Programowa jako wyznacznik wczesnoszkolnej edukacji językowej
}

\begin{abstract}
The article presents research on possible interpretations of Core Curriculum provisions in the area of linguistic education for the $1^{\text {st }}$ educational stage: grades $1-3$, early school education. Core Curriculum is a starting point of planning and organisation of educational process, linguistic education included. While its interpretation is dependent on numerous factors, it was assumed that basic interpretation direction is dictated by the language of the Core Curriculum itself. The objective of the article was to reflect on meanings in Core Curriculum provisions, which become a vital influence on early school language learning. The regarded problem is thus: how does the language of Core Curriculum dictate possible methods of interpretation in educational strategies? Language acquirement theories overview was presented in relation to the school didactics appearing in various pedagogic paradigms. Then, Core Curriculum provisions were analysed and matched to specific didactic options, including their relations to language acquisition theories. In the analysis, category of „linguistic image of the world" was used, which allows to reveal point of view of document authors on theoretical and didactic bases of early school lan-
\end{abstract}

1 Anna Wasilewska, Instytut Studiów Edukacyjnych, Wydział Nauk Humanistycznych i Społecznych, Akademia Marynarki Wojennej im. Bohaterów Westerplatte w Gdyni, Polska, a.wasilewska@ amw.gdynia.pl. 
guage learning. Core Curriculum provisions turn out to be equivocal or even contradictory in relation to the theoretical basis, which implicates chaos in the didactic interpretation.

\section{Keywords:}

Core Curriculum, early school language learning, linguistic competence acquirement theories, didactic approaches, interpretation

\section{WSTĘP}

Pierwsza Podstawa Programowa była związana z reformą oświaty w 1999 roku i została wydana w Dzienniku Ustaw z 14 lutego 1999. Jej ukazanie się wprowadziło nowe zasady organizacji edukacji oraz otworzyło drogę dla wielości i różnorodności programowych, co związane jest z możliwością różnych interpretacji haseł tego dokumentu. Z jednej strony mamy wspólne dla wszystkich ramy kształcenia, narzucone przez zapisy Podstawy Programowej, a z drugiej możliwość uelastycznienia owych ram przez dostosowanie zapisów ustawy do oczekiwań i możliwości podmiotów edukacji. Edukacyjna interpretacja zapisów Podstawy Programowej jest osadzona w pewnych określonych kontekstach, np.: społecznym, kulturowym, geograficznym. Uwzględnianie specyficznych dla danej szkoły kontekstów w praktyce edukacyjnej sprawia, że realizując hasła Podstawy Programowej można wykorzystać lokalnie dostępne zasoby treści. Ukonkretnianie treści dokumentu wspólnego dla wszystkich może prowadzić do przywoływania rzeczywistych doświadczeń uczniów. Tu pojawiają się liczne pytania, np.: na ile w interpretacjach autorskich można „odejść” od ogólnych treści ważnych dla edukacji we wszystkich szkołach, aby sprostać lokalnym potrzebom, specyficznym tylko dla określonej szkoły? I dalej - jak wyważyć możliwości indywidualne z powszechnymi standardami edukacyjnymi? Takie dylematy pojawiają się na różnych poziomach w procesie planowania i realizacji kształcenia - od konstruowania programu nauczania, przez ustalanie szkolnych zestawów programów, które powinny odpowiadać misji szkoły, aż do praktyki konkretnych zajęć edukacyjnych. W końcu, za jeden z ważniejszych wyznaczników praktyki edukacyjnej jest uważany kontekst paradygmatów, który ma znaczenie dla osobistych teorii edukacyjnych nauczycieli (Klus-Stańska, 2009) w odniesieniu do paradygmatu pedagogicznego Podstawy Programowej (Wasilewska, 2013). Chcę tu jednak podkreślić, że chociaż ostateczny przebieg procesu edukacyjnego uzależniony jest od niezwykle złożonych i niejedno- 
znacznych czynników, to pierwszym i podstawowym wyznacznikiem staje się Podstawa Programowa. To właśnie język Podstawy Programowej nadaje kierunek interpretacji poszczególnych jej haseł dla planowania i organizowania procesu edukacji. Dlatego też postanowiłam przyjrzeć się zapisom tego dokumentu dotyczącym kształcenia języka dzieci w klasach młodszych, dokonując refleksji w odniesieniu do teorii przyswajania/uczenia się języka oraz w odniesieniu do dydaktyki.

\section{PODSTAWA PROGRAMOWA I UWARUNKOWANIA JEJ INTERPRETACJI W EDUKACJI - KOMENTARZ METODOLOGICZNY}

Podstawa Programowa jako ogólna „rama” do wypełnienia dla wszystkich, opracowana jest w języku wymagań i oczekiwań odnoszących się do wiedzy i umiejętności dzieci na koniec każdego etapu edukacyjnego. Jaką treścią i w jaki sposób będzie ta „rama” wypełniona, staje się kwestią interpretacji autorów programów nauczania i ich realizatorów. Podstawa Programowa jest w zasadzie jedynym prawnym dokumentem, który musi być respektowany przez podmioty organizujące edukację, tj. szkołę jako instytucję, autorów programów edukacyjnych oraz nauczycieli. Wszystkie programy edukacyjne są jedynie interpretacją haseł Podstawy Programowej, ukonkretnieniem ich, uszczegółowieniem i ewentualnym rozszerzeniem. To daje swego rodzaju wolność - elastyczność w interpretacji haseł tego dokumentu, która jest do pewnego stopnia wykorzystywana przez autorów programów edukacyjnych, chociaż w daleko mniejszym stopniu ujawnia się w praktycznej realizacji na zajęciach w szkole. Sposoby interpretacji Podstawy Programowej zależą od wielu czynników, m.in.:

1) przyjętych podstaw teoretycznych (merytorycznych dla danego przedmiotu oraz psychologicznych);

2) założeń ideologicznych (paradygmatu pedagogicznego autorów programów);

3) kontekstu społecznego i kulturowego (zasobów, oczekiwań, potrzeb, możliwości - szkoły, uczniów, rodziców, społeczności lokalnej).

Ostatecznie jednak to nauczyciel decyduje o sposobach organizacji zajęć, metodach edukacyjnych, a nawet o doborze szczegółowych treści kształcenia. Strategie nauczycielskie w realizacji zadań edukacyjnych uzależnione są od wszystkich tych powyżej przywołanych czynników, składających się na osobiste teorie edukacyjne nauczyciela. Warto zatem zastanowić się nad czynnikami warunkującymi różne możliwe nauczycielskie interpretacje haseł Podstawy Programowej, które 
przejawiają się w codziennych zadaniach dydaktycznych. Interesuje mnie tu problematyka kształcenia języka we wczesnej edukacji.

W odniesieniu do tych treści w kształtowaniu się osobistych teorii nauczyciela, a co za tym idzie, także w konstruowaniu strategii edukacyjnych, można wyodrębnić takie czynniki, jak:

1) wiedza nauczyciela o języku i warunkach rozwoju kompetencji językowych dziecka - podstawy teoretyczne;

2) przyjęte podejście dydaktyczne - założenia ideologiczne, paradygmat pedagogiczny;

3) wiedza o potrzebach rozwojowych, kulturowych i społecznych uczniów konkretnej szkoły - kontekst społeczny i kulturowy.

Powyższe uwarunkowania stanowią o sposobach organizacji kształcenia językowego przez nauczyciela, które zawsze odnoszą się do zapisów Podstawy Programowej. Dlatego właśnie hasła Podstawy Programowej stają się punktem wyjścia dla interpretacji nauczycielskich, a także wyznaczają cele dla konkretnych zadań edukacyjnych.

Chcę wykazać, że zapisy tego dokumentu niosą znaczenia kierujące tokiem interpretacji. Zadaję sobie pytanie: Jak język Podstawy Programowej wyznacza możliwe sposoby interpretacji w strategiach edukacyjnych? Jak Podstawa Programowa kieruje myśleniem nauczyciela? W swoich analizach odwołuję się do wyodrębnionych wcześniej czynników interpretacyjnych:

1) na jakie teorie przyswajania języka wskazują zapisy Podstawy Programowej? - podstawy teoretyczne;

2) jakie wskazówki dla organizowania procesu kształcenia języka niesie Podstawa Programowa? - podejście dydaktyczne;

3) jak w zapisach Podstawy Programowej jest uwzględniana możliwość dostosowania treści i sposobów realizacji celów do specyficznych warunków rozwojowych, społecznych i kulturowych uczniów? - kontekst społeczno-kulturowy.

Warto tu przywołać koncepcję „Językowego Obrazu Świata” (JOS), która pozwoli na przeprowadzenie analizy zapisów Podstawy Programowej w odniesieniu do organizacji edukacji. Podstawą tej koncepcji jest założenie, że każdy język naturalny zawiera w sobie obraz świata specyficzny dla społeczności, która posługuje się tym językiem. Według Wilhelma von Humbolta język jest nie tylko środkiem porozumiewania się, lecz także wyrazem ducha oraz oglądu świata przez użytkowników (Jedliński, 2000). Język dany w treściach semantycznych oraz w kategoriach gramatycznych oraz syntaktycznych ujawnia sposób rozumienia świata, w tym aspekty kulturowe, duchowe i aksjologiczne. W nowszych badaniach 
przyjmuje się istnienie złożonych zależności między językiem a strukturami poznawczymi oraz między językiem a innymi systemami służącymi poznaniu. Stąd kategoria JOS, początkowo zawłaszczana przez lingwistów, jest coraz częściej przywoływana w innych nurtach badawczych. Dla pedagogiki szczególnie użyteczna jest koncepcja wiążąca JOS z lingwistyką kognitywną, w której język może być traktowany jako środek do badań nad procesami poznawczymi, związanymi z wiedzą i rozumieniem. W analizie kognitywnej zdanie staje się „zdarzeniem kognitywnym” (Langacker, 1995).

Gdy mówimy o zdarzeniu w perspektywie kognitywnej, mamy na myśli zdarzenie poznawcze, wyrażone za pośrednictwem określonej (wybranej) formy językowej. Zdarzenie aktualizowane jest w języku przez określoną opcję wyboru punktu widzenia i perspektywy. Bartmiński (1990) definiuje „punkt widzenia” jako czynnik podmiotowo-kulturowy oraz zespół dyrektyw kształtujących treść i strukturę wypowiedzi. Analiza fragmentów aktualnej Podstawy Programowej z perspektywy koncepcji JOS pozwala zrekonstruować punkt widzenia autorów tekstu tego dokumentu, by ujawnić zespół dyrektyw dotyczących podstaw teoretycznych i dydaktycznych wraz z kontekstem kulturowym. Owe dyrektywy w sposób niejawny wytyczają kierunek dla interpretacji edukacyjnych, dlatego warto się im przyjrzeć i przyporządkować do określonej opcji teoretycznej. Odwołując się do kategorii Językowego Obrazu Świata, wyodrębniam z zapisów Podstawy Programowej formy językowe (wskaźniki językowe), które niosą znaczenia ważne dla organizowania kształcenia języka dziecka. Są to pojedyncze słowa, złożone wyrażenia lub całe zdania, które wskazują na określony punkt widzenia autorów w odniesieniu do podstaw teoretycznych i podejścia dydaktycznego.

\section{TEORIE PRZYSWAJANIA JĘZYKA I ICH IMPLIKACJE W EDUKACJI}

Wiedza nauczyciela o języku jest pragmatyczna, ponieważ realizacja zadań edukacyjnych wymaga odniesienia do sytuacji poznawczej konkretnych uczniów - ich możliwości, umiejętności i oczekiwań oraz środowiska społeczno-kulturowego, w jakim przebiega kształcenie. Zatem w planowaniu i organizowaniu procesu kształcenia językowego ważne staje się przede wszystkim rozumienie warunków funkcjonowania językowego ucznia oraz skomplikowanych powiązań między językiem a sferą poznawczą jednostki. Nauczycielskie rozumienie procesu uczenia/uczenia się języka kształtuje się przede wszystkim na podstawie poznanych teorii lingwistycznych. W odniesieniu do podejmowanej tu problematyki istotne są koncepcje dotyczące przebiegu i mechanizmów przyswajania/uczenia się języka 
ojczystego oraz języka obcego. Należy zdefiniować, jak rozumiane jest tu „przyswajanie języka”, by odróżnić to pojęcie od „uczenia się języka”. Otóż przyswajanie języka jest procesem naturalnego rozwoju kompetencji językowych w toku życia. To proces częściowo utajony, związany z rozwojem psychopoznawczym jednostki. Kompetencja językowa utajona ma charakter proceduralny, tworzy zautomatyzowane schematy zachowań językowych. Natomiast uczenie się ma charakter jawny i może być realizowane w zadaniach edukacyjnych wytyczanych przez podmiot uczący się (samoedukacja) bądź przez nauczyciela (edukacja). Właśnie przez uczenie się konstruowana jest wiedza metajęzykowa jawna, formalna, która ma charakter deklaratywny. Wydaje się, że najwłaściwsze będzie tu zastosowanie terminu „nabywanie kompetencji językowych”, który łączy oba procesy rozwoju języka, tak naturalny, utajony, jak i celowe uczenie się. We wczesnym rozwoju językowym te mechanizmy czasami trudno rozróżnić, np. w zabawach językowych dziecka.

Zagadnieniem rozwoju kompetencji językowych, zarówno w procesie przyswajania języka, jak i uczenia, zajmują się różne dziedziny lingwistyki, przede wszystkim psycholingwistyka, a w jej ramach lingwistyka rozwojowa. W obrębie tej nauki podejmowane są badania nad rozumieniem i percepcją mowy, dostępem leksykalnym, tworzeniem wypowiedzi, dyskursem, a także nad procesem przyswajania języka - nabywaniem umiejętności językowych przez dzieci w poszczególnych etapach rozwoju i uczeniem się języków obcych. Ważne badania dla refleksji nad edukacją językową znajdujemy także w socjolingwistyce, która zajmuje się znaczeniem czynników społecznych dla rozwoju języka oraz językowym funkcjonowaniem jednostki w grupach społecznych. Współcześnie w teoriach dotyczących językowego funkcjonowania człowieka, które mają znaczenie dla edukacji językowej, ujawnia się zainteresowanie teorią umysłu, badaniami neurolingwistycznymi, psycholingwistyką stosowaną (czytanie, pisanie, dwujęzyczność) oraz biolingwistyką (genetyczne i biologiczne uwarunkowania języka). Definiując z rozmaitych perspektyw badawczych poszczególne aspekty procesu rozwoju kompetencji językowych dziecka, teorie stwarzają raczej pole do mnożenia kontrowersji. Pojawiają się pytania: natura czy wychowanie, ciągłość czy stadia, uniwersalna kompetencja czy zróżnicowanie indywidualne, struktura czy funkcja, reguły czy skojarzenia (Gleason, Ratner, 2005)? Odpowiedzi na te pytania różnicują teorie dotyczące rozwoju języka, a za najważniejszą, także jeśli chodzi o konsekwencje dla edukacji, jest uważana kwestia pierwsza - w jakim stopniu język jest zaprogramowany w strukturach mózgu (natura), a jakim wyuczony w toku interakcji ze środowiskiem (edukacja)? Z perspektywy edukacji można wyodrębnić trzy podstawowe podejścia (Czelakowska, 1996) do rozwoju językowego: 


\section{Teorie, w których główną rolę w nabywaniu kompetencji językowych przy-} pisuje się czynnikowi zewnętrznemu. Do tego nurtu koncepcji należą teorie behawiorystyczne, teorie uczenia się, teorie socjolingwistyczne. W teoriach tych podkreśla się znaczenie wzmocnienia płynącego od otoczenia do dziecka w rozwoju kompetencji językowych. Dziecko uczy się języka przez naśladowanie lub/i stymulowanie przez środowisko społeczne. Pozytywne wzmocnienia dotyczą tych cech zachowań językowych, które są zgodne z modelem języka w danej grupie społeczno-kulturowej. Najbardziej radykalne podejście w tej kwestii jest związane z teorią behawiorystyczną, której tezy są tradycyjnie mocno zakorzenione w praktyce szkolnej, co przejawia się chociażby w tendencji do wyznaczania celów operacyjnych czy sprawdzania wiedzy w testach.

Istota uczenia się: Aktywność dziecka jest zależna od sterowania przez ludzi w jego otoczeniu. Nabywanie kompetencji językowych jest rozumiane jako proces naśladowczy. Kompetencje językowe - jako skończony zbiór wyznaczonych reakcji werbalnych. Posługiwanie się językiem ma charakter odtwórczy.

Konsekwencje dydaktyczne: Skoncentrowanie na poprawności wypowiedzi ucznia; wyszukiwanie błędów w wypowiedziach i poprawianie; zadania według wzoru; kształcenie umiejętności poprzez wielokrotność powtórzeń; wymaganie odtwarzania wiedzy (testy); wymaganie wiedzy formalnej o języku.

\section{Teorie, które akcentują znaczenie czynnika wewnętrznego: teoria lingwi-} styczno-natywistyczna, teorie poznawcze, modele neurolingwistyczne. Według tych koncepcji człowiek posiada specyficzną zdolność do dedukowania reguł danego języka, lub/i rozwój języka związany jest z dojrzewaniem poznawczym jednostki. Współczesne teorie lingwistyczne dotyczące rozwoju języka w różnym stopniu odwołują się do natywistycznej teorii Chomsky’ego (1975). Chomsky dowodził, że fundamentalny system gramatyczny umożliwiający uczenie się języka jest wrodzoną cechą ludzi i stanowi o specyfice naszego gatunku. Ta wrodzona wiedza językowa określana jest terminem gramatyki uniwersalnej. Jest to specyficznie ludzka zdolność do dedukowania zasad danego języka z obserwacji wypowiedzi osób z otoczenia. Chomsky opisuje różnice pomiędzy językami ludzkimi w kategoriach „ustawienia parametrów w mózgu”. Nauka języka przez dziecko miałaby polegać na uczeniu się specyficznych cząstek leksykalnych (słowa, morfemy, idiomy) i na ustawianiu parametrów-przełączników na podstawie jedynie kilku przykładów podanych dziecku. Teoria ta tłumaczy, dlaczego dzieci potrafią nauczyć się języka bardzo szybko. Na prawidłowość natywistycznej teorii wskazują typy błędów popełnianych przez dzieci w trakcie nauki języka, a także obserwowana nieobecność innych błędów, teoretycznie dozwolonych. Teorie 
natywistyczne mają duże znaczenie dla konstruowania koncepcji dotyczących rozwoju języka oraz przyjmowania strategii edukacyjnych.

Istota uczenia się języka: Człowiek ma potencjalną zdolność do posługiwania się językiem. Strategią uczenia się języka jest metoda rozwiązywania problemów (tworzenie szeregu hipotez i ich weryfikacja). Konstruuje się wiedza metajęzykowa utajona (nieformalna). Dziecko odkrywa reguły językowe w obserwacji wypowiedzi innych i w przetwarzaniu ich w różnych własnych wypowiedziach (zabawy językiem, język w zabawie). Uczenie się języka przez dziecko ma charakter twórczy.

Konsekwencje dydaktyczne: Błędy językowe dziecka są interpretowane jako świadectwo poszukiwania reguł językowych. Organizuje się bogate środowisko językowe przez umożliwianie obserwacji różnych zachowań językowych, zabawy językowe, twórcze zadania. Kształcenie dziecka dotyczy w szerokim zakresie nabywania umiejętności praktycznych (wiedza proceduralna).

\section{Teorie, które uwzględniają współzależność czynnika zewnętrznego, czyn- nika wewnętrznego i aktywności własnej podmiotu: teorie interakcji społecznej,} niektóre teorie poznawcze, niektóre teorie socjolingwistyczne. Do tego nurtu należą koncepcje, w których rozwój jest możliwy dzięki specyficznej własności poznawczej typowej dla ludzi, jednak ważna jest tu także aktywność jednostki oraz jakość społecznego kontekstu. Złożone czynniki rozwoju języka opisywane są w teoriach znaczących dla edukacji wczesnoszkolnej - Jeana Piageta, Lwa Wygotskiego, Jeroma Brunera. Rozwój poznawczy jest warunkiem rozwoju językowego, zaś rozwój języka następuje zgodnie z rozwojem pojęć i znaczeń. Pojęcie nie jest możliwe bez słów, a myślenie pojęciowe bez myślenia werbalnego. Źródłem nabywania kompetencji językowych są procesy poznawania i działanie oraz doświadczenie jednostki.

Piaget twierdził (1999), że najważniejsze czynniki rozwoju językowego leżą po stronie podmiotu, ponieważ warunkiem jest dojrzewanie organizmu i aktywność własna dziecka (naturalna motywacja do rozwoju). Wygotski (1989) obok czynników podmiotu wskazał czynnik wychowawczy, sterujący i stymulujący. Proces rozwoju intelektualnego pobudza czynnik oddziaływania społecznego - odpowiednio wyznaczane zadania. Bruner (1966) ponadto podkreśla rolę czynnika kulturowego w rozwoju języka. Uczyć się reguł językowych, to znaczy przyswajać sobie normy kulturowe, które mają swoje odbicie w języku. Teorie socjolingwistyczne (Bernstein, 1990; Halliday, 1980) akcentują znaczenie środowiska społeczno-językowego, w jakim przebiega uczenie się języka. Dziecko uczy się znaczeń dzięki informacjom o funkcjonowaniu wypowiedzi w kontekście społecznym. Rozwój 
języka dziecka jest organizowany przez dążenie do opanowania podstawowych funkcji mówienia: przedstawiającej i interpersonalnej, które od samego początku kierują myśleniem i mówieniem. Dziecko staje się dzięki językowi aktywnym poszukiwaczem i eksperymentatorem, poznając i wypróbowując jego funkcje w kontaktach społecznych. Rozwój języka w teoriach tego nurtu ma charakter odtwórczo-twórczy.

Istota uczenia się języka: Uczenie się języka jest stymulowane przez uczestniczenie w językowej komunikacji z rówieśnikami i dorosłymi. Język ma charakter funkcjonalny w stosunku do rzeczywistości poznawanej. Jest narzędziem myślenia i środkiem komunikowania się. Postęp kompetencji językowej może być skutecznie stymulowany przez zadania wykraczające poza sferę aktualnego rozwoju, skierowane do sfery możliwego poziomu rozwoju jednostki. Konieczność porozumiewania się w coraz szerszym kręgu ludzi jest motorem nabywania i kształtowania przez dziecko bardziej skomplikowanych struktur językowych.

Konsekwencje dydaktyczne: Kształcenie językowe towarzyszy wszelkiej aktywności edukacyjnej, szczególnie w obecności mowy eksploracyjnej. Dla tych podstaw teoretycznych charakterystyczne jest wyznaczanie zadań dostosowanych do poziomu kompetencji konkretnych dzieci (zadania wielopoziomowe). Ważny staje się w edukacji aktywny kontakt ze światem społecznym, materialnym i kulturowym, udzielanie odpowiedzi na ciekawość poznawczą dziecka i niehamowanie jego poszukiwań. Organizuje się zadania otwarte, twórcze, z preferowaniem pracy w grupie.

Syntetycznie opisane powyżej podstawy teorii dotyczących procesu rozwoju kompetencji językowych można odnieść do różnych podejść dydaktycznych:

Podejście behawiorystyczne. Program definiowany jest jako plan działań, wskazujący strategie założonych celów i rezultatów. To swoisty „przepis na działanie”, charakteryzujący się wysokim stopniem szczegółowości i liniowością. Tutaj cele i zadania edukacyjne wynikają z potrzeb „ogółu”, którym podporządkowane są potrzeby jednostki. Jednostka ma sprostać zewnętrznie wytyczonym normom, w konkretnym etapie kształcenia.

Podejście humanistyczne. Program ujmuje się w kategoriach doświadczeń ucznia. Definiowany jest jako szczególne środowisko nastawione na pomaganie dzieciom w ich samorealizacji dokonującej się poprzez ich aktywną działalność w szkole. Najważniejsze w edukacji jest wspieranie indywidualnego rozwoju dziecka, zgodnie z jego możliwościami i potrzebami, w indywidualnym tempie.

Podejście progresywistyczne. Program definiuje się jako ogół złożonych pod względem psychologicznym i filozoficznym doświadczeń edukacyjnych ucznia, 
prowadzących do indywidualnego nadawania znaczeń oraz aktywnego włączania się w transformację rzeczywistości. Najszerzej ujmuje cele edukacyjne, ponieważ pozwala na wyważenie potrzeb jednostki i społeczeństwa.

\section{ANALIZA ZAPISÓW PODSTAWY PROGRAMOWEJ W ODNIESIENIU DO KSZTAŁCENIA JĘZYKA OJCZYSTEGO ORAZ JĘZYKA OBCEGO}

Najnowsza Podstawa Programowa jest opublikowana w Dzienniku Ustaw 2017, poz. 356, na podstawie Rozporządzenia Ministra Edukacji Narodowej z 14 lutego 2017 r. w sprawie podstawy programowej wychowania przedszkolnego oraz podstawy programowej kształcenia ogólnego dla szkoły podstawowej. Jest to dokument publicznie dostępny na stronie internetowej MEN, a także w wersji drukowanej - w placówkach oświatowych i bibliotekach. Poddałam analizie fragmenty tego dokumentu, dotyczące kształcenia języka dziecka w pierwszym etapie edukacji (w klasach I-III).

Sformułowania dotyczące mówienia pojawiają się w opisie różnych obszarów rozwoju dziecka. W części poświęconej celom edukacyjnym, które ustalają osiągnięcia dziecka na koniec pierwszego etapu kształcenia, wyrażenia dotyczące mówienia pojawiają się w trzech na cztery obszarach. Brak takich określeń w punkcie: „I. W zakresie fizycznego obszaru rozwoju”.

\section{Słowa i wyrażenia związane z mówieniem:}

„II. W zakresie emocjonalnego rozwoju uczeń osiąga: umiejętność [...] nazywania” (swoich emocji i uczuć); „umiejętność [...] nazywania” (emocji i uczuć innych osób); „umiejętność przedstawiania (swoich emocji) w prostej wypowiedzi ustnej”; „umiejętność wyrażania [...] za pomocą wypowiedzi ustnej”;

„III. W zakresie społecznego obszaru rozwoju uczeń osiąga: [...] umiejętność [...] nazywania” (wartości): „umiejętność [...] nazywania” (grup społecznych i ich cech);

„IV. W zakresie poznawczego obszaru rozwoju uczeń osiąga: umiejętność poprawnego posługiwania się językiem polskim w mowie [...] pozwalającą na samodzielną aktywność, komunikację i efektywną naukę”; „umiejętność rozumienia i używania prostych komunikatów w języku obcym”. 
Wnioski: W części Podstawy Programowej dotyczącej celów kształcenia dominują określenia związane z nazywaniem, a więc najbardziej elementarne formy wypowiedzi. Ponadto jest jedno określenie wskazujące na poprawność i jedno na rozumienie i używanie prostych komunikatów w języku obcym. Brakuje celów tyczących rozwoju kompetencji językowych i komunikacyjnych, umiejętności badania i twórczości językowej. Zastosowane określenia kierują uwagę w stronę dydaktyki o podstawach behawiorystycznych.

W części: „Treści - wymagania szczegółowe” znajduje się więcej bardziej złożonych efektów kształcenia:

„1. Osiągnięcia w zakresie słuchania: słucha z uwagą wypowiedzi nauczyciela i innych osób”; „zadaje pytania”; „szuka własnych wzorów poprawnej artykulacji i interpretacji słownej w języku ojczystym”.

Wniosek: Pojawiają się w tym zapisie wskazania na twórcze dochodzenie do poprawności językowej dziecka, co jest zgodne z teoriami natywistycznymi i co kieruje uwagę w stronę dydaktyki progresywistycznej. W wyrażeniach: „słucha i czeka na swoją kolej”, „panuje nad chęcią nagłego wypowiadania się” można znaleźć odniesienia do społeczno-kulturowych konwencji dotyczących mówienia dziecka, a więc do podstaw socjolingwistyki oraz teorii wieloczynnikowej zależności w rozwoju języka. Jednocześnie mocne akcentowanie norm zapisanych w języku (słucha, czeka, panuje nad chęcią) odsłania podejście behawiorystyczne w dydaktyce.

„2. Osiągnięcia w zakresie mówienia: wypowiada się płynnie, wyraziście, stosując adekwatne do sytuacji techniki języka mówionego”; „formułuje pytania”; „,wypowiada się w formie uporządkowanej”; „porządkuje swoją wypowiedź”; ,poprawia błędy”; „omawia treść”; „układa w formie ustnej”; „,składa ustne wypowiedzi”; ,dobiera stosowną formę”; , ,eksperymenty językowe”; „tworzy charakterystyczne dla siebie wypowiedzi”.

Wnioski: W szczegółowej części dokumentu dominują określenia dotyczące panowania nad formą wypowiedzi i techniką wypowiadania. Znalazły się też pojedyncze określenia dotyczące badania (eksperymentów) i tworzenia własnego stylu mówienia. Znajdujemy tu pewne odniesienia do dydaktyki progresywistycznej, przede wszystkim w opisie wskazówek metodycznych, np.: „Nauczyciele organizują edukację dzieci jako dynamiczny proces nadawania osobistego sensu 
i rozumienia ciągle zmieniającej się rzeczywistości”; „proces edukacji umożliwia eksplorację świata, zdobywanie nowych doświadczeń i interakcję z otoczeniem”. Jednak w opisie szczegółowych wymagań, odnoszących się do kategorii mówienia, jest zwrot w kierunku dydaktyki behawiorystycznej, co przejawia się w nastawieniu na poprawność, formę i konwencjonalność oraz w zadaniach według wzoru:

„wykonuje zadanie według usłyszanej instrukcji”; „układa i zapisuje opowiadanie złożone z 6-10 poprawnych wypowiedzeń”; „przestrzega poprawności ortograficznej w wyrazach”; „stosuje poprawnie znaki interpunkcyjne”; „zapisuje poprawnie liczebniki; stosuje poprawną wielkość liter w zapisie”.

Kategoria postępu/rozwoju jest definiowana jako dążenie do poprawności wypowiedzi i w nielicznych zapisach jako poszukiwanie własnego stylu wypowiedzi. Jedynie zapisy dotyczące osiągnięć w zakresie samokształcenia odnoszą się do teorii natywistycznych oraz wieloczynnikowych, które kierują uwagę w dydaktyce na poszukiwanie, eksperymentowanie i twórczy proces nabywania kompetencji językowych:

„podejmuje próby zapisu nowych, samodzielnie poznanych wyrazów i sprawdza poprawność ich zapisu, korzystając ze słownika ortograficznego; korzysta z różnych źródeł informacji, np. atlasów, czasopism dla dzieci, słowników i encyklopedii czy zasobów internetu i rozwija swoje zainteresowania; wykorzystuje nabyte umiejętności do rozwiązywania problemów i eksploracji świata, dbając o własny rozwój i tworząc indywidualne strategie uczenia się".

Warto zauważyć, że w tym zapisie poprawność jest traktowana inaczej niż w poprzednich. Tu ujawnia się dochodzenie do poprawności w aktywności poznawczej jednostki, co wskazuje na podstawy natywistyczne oraz podejście progresywistyczne, podczas gdy we wcześniejszych zapisach poprawność ma charakter narzuconej z zewnętrz normatywności (podejście behawiorystyczne). 


\section{KONKLUZJE}

1) Na jakie teorie przyswajania języka wskazują zapisy Podstawy Programowej?

Tabela 1. Wskaźniki językowe ujawniające podstawy teoretyczne

\begin{tabular}{ll}
\hline Podstawy teoretyczne & Wskaźniki językowe \\
\hline $\begin{array}{l}\text { I. Teorie czynnika } \\
\text { zewnętrznego }\end{array}$ & $\begin{array}{l}\text { wykonuje zadanie według instrukcji; poprawnie rozmieszcza; wła- } \\
\text { ściwie; poprawnych wypowiedzeń; poprawnie formułuje; reaguje na } \\
\text { polecenia; w ramach wyuczonych zwrotów }\end{array}$ \\
\hline $\begin{array}{l}\text { II. Teorie czynnika } \\
\text { wewnętrznego }\end{array}$ & $\begin{array}{l}\text { porządkuje swoją wypowiedź, poprawia w niej błędy; wykonuje } \\
\text { eksperymenty językowe; nadaje znaczenie czynnościom } \\
\text { i doświadczeniom, tworząc charakterystyczne dla siebie formy wy- } \\
\text { powiedzi; rozpoznaje; przekształca; łączy wyrazy w wypowiedzenia; } \\
\text { podejmuje próby; znajduje w wypowiedzi określone informacje }\end{array}$ \\
\hline $\begin{array}{l}\text { III. Teorie wieloczyn- } \\
\text { nikowe }\end{array}$ & $\begin{array}{l}\text { formułuje pytania dotyczące sytuacji zadaniowych; dobiera stosowną } \\
\text { formę komunikacji werbalnej; korzysta z różnych źródeł informacji }\end{array}$ \\
\hline
\end{tabular}

Źródło: Opracowanie własne.

Zastosowanie w wielu hasłach Podstawy Programowej wyrażeń dotyczących poprawności, uporządkowania, sprawdzania, odtwarzania i wykonywania według wzoru świadczy o dominujących podstawach teorii, które za najważniejszy czynnik rozwoju językowego uznają ingerencję zewnętrzną. Kieruje to drogę interpretacyjną w stronę podejścia behawiorystycznego. Zauważalna jest jednak wyraźna niekonsekwencja w przyjętych podstawach teoretycznych. W niektórych zapisach, szczególnie dotyczących wskazówek metodycznych oraz samokształcenia, pojawiają się wyrażenia dotyczące badania, poszukiwania, eksploracji, twórczości językowej. Widać więc tu echo koncepcji natywistycznych oraz tych, które podkreślają znaczenie aktywności poznawczej podmiotu w nabywaniu kompetencji językowej lub koncepcji poznawczych, łączących rozwój języka z rozwojem myślenia. W zapisach Podstawy Programowej pojawiają się także nieliczne określenia, które wskazują na kulturowo-społeczne uwikłania rozwoju języka. Niestety, wyrażenia stosowane w zapisach Podstawy Programowej w dużej mierze odsyłają do wdrażania do normatywności (podejście behawiorystyczne), a nie otwierają na twórcze funkcjonowanie językowe w świecie społecznym (podejście socjolingwistyczne czy kulturowe). Stosowane w Podstawie Programowej wyrażenia językowe nie dają czytelnej wykładni interpretacyjnej - w wielu miejscach są sprzeczne teoretycznie, co nie pomoże nauczycielom w organizowaniu procesu kształcenia.

2) Jakie wskazówki dydaktyczne dla organizowania procesu kształcenia języka niesie Podstawa Programowa? 
Tabela 2. Wskaźniki językowe ujawniające podejście dydaktyczne

\begin{tabular}{ll}
\hline Podejście dydaktyczne & Wskaźniki językowe \\
\hline & $\begin{array}{l}\text { słucha i czeka na swoją kolej, panuje nad chęcią nagłego wypo- } \\
\text { wiadania się; poprawnych wypowiedzeń; stosuje poprawnie znaki; } \\
\text { porządkuje wyrazy; układa i zapisuje zdarzenia we właściwej } \\
\text { kolejności; pisze bardzo proste i krótkie zdania według wzoru; } \\
\text { zapisuje poprawnie }\end{array}$ \\
\hline II. Humanistyczne & $\begin{array}{l}\text { dbając o własny rozwój; szuka własnych wzorów poprawnej arty- } \\
\text { kulacji i interpretacji słownej }\end{array}$ \\
\hline \multirow{2}{*}{ III. Progresywistyczne } & $\begin{array}{l}\text { wykorzystuje nabyte umiejętności do rozwiązywania problemów } \\
\text { i eksploracji świata; tworząc indywidualne strategie uczenia się; } \\
\text { współpracuje z rówieśnikami w trakcie nauki; korzysta ze źródeł } \\
\text { informacji w języku obcym nowożytnym }\end{array}$ \\
\hline
\end{tabular}

Źródło: Opracowanie własne.

Niejednoznaczne podstawy teoretyczne implikują rozmyte kierunki dydaktyczne. W niektórych zapisach, dotyczących celów ogólnych oraz samokształcenia, stosowane wyrażenia odsyłają do podejścia progresywistycznego. Ma to miejsce przede wszystkim w hasłach odnoszących się do nauki języka obcego - tylko w tym miejscu jest mowa o pracy językowej z rówieśnikami. W bardzo niewielkim zakresie pojawią się wyrażenia, które można przypisać do podejścia humanistycznego. W szczegółowych wymaganiach stosowane są jednak przede wszystkim wyrażenia dotyczące poprawności, normatywności i wykonywania według wzoru, a więc podejścia behawiorystycznego. Zapisany w języku Podstawy Programowej chaos wskazówek dydaktycznych może przekładać się na zagubienie nauczyciela. W tym najważniejszym w edukacji dokumencie nie znajduje on czytelnych wskazówek dla wyznaczania zadań edukacyjnych i skutecznego wspierania rozwoju kompetencji językowych ucznia.

3) Jak w zapisach Podstawy Programowej jest uwzględniana możliwość dostosowania treści i sposobów realizacji celów do specyficznych warunków rozwojowych, społecznych i kulturowych uczniów?

W wielu zapisach Podstawy Programowej, szczególnie we wskazówkach metodycznych, znalazły się wyrażenia dotyczące dostosowania edukacji językowej do uczniów ze specjalnymi potrzebami edukacyjnymi, brakuje jednak zapisów wskazujących na potrzebę stosowania zadań wielopoziomowych dla wszystkich dzieci. Wynika to z braku odniesień do teorii poznawczych (np. Wygotskiego). Brak takich wskazówek sprawia, że edukacja ma charakter sztywny - zadania są takie same dla wszystkich, niezależnie od indywidualnych potrzeb i możliwości 
uczniów. Specyficzne warunki społeczne i kulturowe są uwzględnione w zapisach haseł w pojedynczych określeniach, dotyczących eksploracji, badania i korzystania z różnych źródeł informacji. Kontekst społeczno-kulturowy jest w języku Podstawy Programowej obecny przede wszystkim w akcentowaniu poprawności i powściągliwości językowej. Brak jest uwzględnienia kontekstu doświadczeń poznawczych i językowych ucznia. Zapisy tego dokumentu w niewielkim zakresie umożliwiają elastyczność interpretacji, by w zadaniach edukacyjnych uczeń mógł odnaleźć siebie - swoje doświadczenia, umiejętności i aby lepiej funkcjonował w świecie społecznym i kulturowym.

Jakim jest zatem wyznacznikiem Podstawa Programowa dla wczesnoszkolnej edukacji językowej? Dokument ten nie odpowiada na pytania dotyczące rozumienia procesu nabywania kompetencji językowych, ponieważ odniesienia do podstaw teoretycznych są niejednoznaczne, a nawet zapisy poszczególnych haseł są wobec siebie sprzeczne. Zapisy tego dokumentu nie wyjaśniają jak jest rozumiany przebieg uczenia się języka, w związku z tym trudno dokonać implikacji edukacyjnych. Podobny nieład dotyczy wskazówek dydaktycznych, więc ukonkretnienie treści Podstawy Programowej w zadaniach szkolnych staje się zadaniem niezwykle trudnym. Dominujące w dokumencie określenia dotyczące poprawności i normatywności kierują interpretację w stroną dydaktyki odtwórczej, sztywnej - o podstawach behawiorystycznych. Pewne nadzieje na dydaktykę elastyczną, otwartą, twórczą dają pojedyncze zapisy - te, które dotyczą samokształcenia, oraz te, które wskazują na możliwości korzystania z różnych źródeł. Jednak sprzeczności w odniesieniu do podstaw teoretycznych sprawiają, że te nieliczne zapisy nie mogą stanowić ważnego wyznacznika dla językowej edukacji dzieci w klasach młodszych.

\section{Bibliografia}

Bartmiński, J. (red.) (1999). Językowy obraz świata. Lublin: Wyd. UMC-S.

Bernstein, B. (1980). Socjolingwistyczne ujęcie procesu socjalizacji: uwagi dotyczące podatności na oddziaływania szkoły. W: G.W. Shugar, M. Smoczyńska (red.), Badania nad rozwojem języka dziecka: wybór prac. Warszawa: Państwowe Wydawnictwo Naukowe.

Chomsky, N. (1982). Zagadnienia teorii składni. Wrocław: Zakład Narodowy im. Ossolińskich.

Gleason J.B., Ratner N.B. (2005). Psycholingwistyka. Gdańsk: GWP.

Halliday, M.A.K. (1980). Uczenie się znaczeń. W: G.W. Shugar, M. Smoczyńska (red.), Badania nad rozwojem języka dziecka: wybór prac. Warszawa: Państwowe Wydawnictwo Naukowe. 
Jedliński, R. (2000). Językowy obraz świata wartości w wypowiedziach uczniów kończących szkołę podstawową. Kraków: Wydawnictwo Naukowe Akademii Pedagogicznej w Krakowie.

Klus-Stańska, D. (2009). Dyskursy pedagogiki wczesnoszkolnej. W: D. Klus-Stańska, M. Szczepska-Pustkowska (red.), Pedagogika wczesnoszkolna: dyskursy, problemy, rozwiązania. Warszawa: Wydawnictwo Akademickie i Profesjonalne.

Langacker, R.W. (1995). Wykłady z gramatyki kognitywnej. Kazimierz nad Wisłą, grudzień 1993. Lublin: Wydawnictwo UMC-S.

Piaget, J. (1992). Mowa i myślenie u dziecka. Warszawa: Wydawnictwo Naukowe PWN. Wasilewska, A. (2013). „Błędy i wypaczenia” czy strach przed wolnością? Nowa Szkoła, R. LXIX, 709, s. 29-34.

Wygotski, L.S. (1989). Myślenie i mowa. Warszawa: Wydawnictwo Naukowe PWN. 